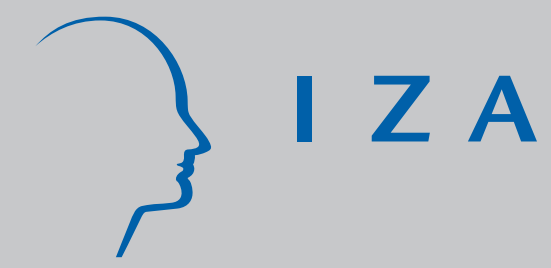

IZA DP No. 235

Who gets the Reward? An Empirical Exploration of Bonus Pay and Task Characteristics

Wendelin Schnedler

December 2000 


\title{
Who gets the Reward? An Empirical Exploration of Bonus Pay and Task Characteristics
}

\author{
Wendelin Schnedler \\ IZA, Bonn
}

\author{
Discussion Paper No. 235 \\ December 2000
}

\author{
IZA \\ P.O. Box 7240 \\ D-53072 Bonn \\ Germany \\ Tel.: +49-228-3894-0 \\ Fax: +49-228-3894-210 \\ Email: iza@iza.org
}

This Discussion Paper is issued within the framework of IZA's research area The Future of Work. Any opinions expressed here are those of the author(s) and not those of the institute. Research disseminated by IZA may include views on policy, but the institute itself takes no institutional policy positions.

The Institute for the Study of Labor (IZA) in Bonn is a local and virtual international research center and a place of communication between science, politics and business. IZA is an independent, nonprofit limited liability company (Gesellschaft mit beschränkter Haftung) supported by the Deutsche Post AG. The center is associated with the University of Bonn and offers a stimulating research environment through its research networks, research support, and visitors and doctoral programs. IZA engages in (i) original and internationally competitive research in all fields of labor economics, (ii) development of policy concepts, and (iii) dissemination of research results and concepts to the interested public. The current research program deals with (1) mobility and flexibility of labor markets, (2) internationalization of labor markets and European integration, (3) the welfare state and labor markets, (4) labor markets in transition, (5) the future of work, (6) project evaluation and (7) general labor economics.

IZA Discussion Papers often represent preliminary work and are circulated to encourage discussion. Citation of such a paper should account for its provisional character. 
IZA Discussion Paper No. 235

December 2000

\section{ABSTRACT \\ Who gets the Reward? An Empirical Exploration of Bonus Pay and Task Characteristics*}

Contract theory predicts that workers are remunerated based on all available unbiased individual performance measures. In the real world, measures are often biased: tasks are too complex to include all measures, unforeseen contingencies occur for which contracts specify nothing, and the necessity of cooperation and coordination at tasks would be undermined by purely individual measures. Hence, alternative incentive mechanisms are employed (implicit contracts, efficiency wages, wage profiles, tournaments). This suggests that bonus pay is linked to task characteristics: complex tasks will be negatively related to bonus pay, unforeseen contingencies and the necessity to cooperate or coordinate will be positively correlated to premiums on aggregated levels such as team or firm bonus. The present article explores these relations using a French cross-sectional micro-data set. While complexity is found not to be negatively related to bonus pay, the other two effects are supported by the data.

JEL Classification: J33

Keywords: Incentive schemes, bonus pay, three-variate probit

Wendelin Schnedler

P.O. Box 7240

D-53072 Bonn

Germany

Tel.: +492283894526

Fax: +492283894510

Email: schnedler@iza.org

\footnotetext{
* An earlier version of this paper had the title "Firm's choice of incentive schemes". Estimations were carried out during a stay at CREST, Laboratoire de Microéconometrie (Paris), whose cooperation is greatly acknowledged. The author likes to thank Wolfgang Schwerdt, Laurent Gobillon, Jean-Marc Robin, Joseph Lafranchi, Rainer Winkelmann, Bruce Shearer, Bentley MacLeod, David Margolis, and participants of the internal seminars at IZA, CREST, and TEAM (Université Paris 1, la Sorbonne), and the participants of the Journées de Microéconomie Appliquée 2000 in Quebec for helpful suggestions and comments. All errors remain my own.
} 


\section{Introduction}

This paper concerns a topic which has been extensively studied in economic theory: the hidden action problem. In particular, we will deal with the situation were the principal is an employer who wants to induce the agent, the employee, to carry out tasks which cannot or only partially be observed or contracted on. The existing literature proposes several solutions to this problem ranging from formal contracts which condition payments on signals (see e.g. Dye (1986), Holmström (1982), Holmström and Milgrom (1991), Salanié (1998)), efficiency wages (Shapiro and Stiglitz 1984), tournament theory (Lazear and Rosen (1981), Green and Stockey (1983)) to implicit contracts (Bull (1987), Rosen (1985)). The empirical implications of these models have been tested by several authors, respective literature surveys can be found in Prendergast (1999), Malcomson (1999), Gibbons (1996), or in the special issue of the Industrial and Labor Relations Review on incentives published in 1990 .

The question which type of solution will be selected by the employer has not been studied nearly as extensively: Baker, Gibbons, and Murphy (1999) explain the choice between relational and formal performance contracts and Lazear (1995) organises his monograph on personnel economics along dichotomous choices of the firm, e.g. between fixed versus variable pay or absolute versus relative evaluation. Some of these choices were analysed empirically: Brown (1990) as well as Pelé (1997) examine the incidence of fixed pay versus piece rates; Dupuy and Lafranchi (1998) deal with the decision between absolute and relative pay; MacLeod and Parent (1998) finally estimate a sequence of choices consisting of the question whether to remunerate deterministically or stochastically, in form of hourly wages or by piece rates, using a formal or an informal contract, and finally by making bonus payments to good workers or firing bad workers.

Similarly to the quoted studies, we want to examine firm's choice of the remuneration scheme empirically. The approach taken in this paper, however, focuses on the level at which performance is remunerated, i.e. we examine when firms give individual, team, or firm bonuses.

To find out about firm's behaviour, we use a data set (ECMOSS 1992) which is particularly apt to our approach: first, it includes detailed information on various types of bonus payments; second, there is information on the tasks which can be related to the used remuneration scheme; finally, all this information is observed post-wise, so that inference need not rely on aggregated 
quantities.

The remainder of the article is organised as follows: we will begin by sketching a theoretical framework in which the empirical analysis can be placed in section 2 , then we propose a statistical model to explore the relation between job characteristics and remuneration in section 3; the data will be introduced in section 4; The estimation results are presented in section 6 ; section 7 concludes.

\section{Theoretical motivation and hypotheses}

We will not derive a fully-fledged theoretical model in this section; rather, we present a general setting, and formulate three basic principles which firms will probably respect when deciding on remuneration schemes.

As in the classical analysis of the firm, the latter is assumed to maximise profits; differently, labour is not homogeneous but rather a vector of tasks which need to be accomplished in order to produce the product or render the service offered by the firm. We suppose that there exists a production plan, i.e. a fixed assignment of these tasks to posts. One could imagine that this production plan results from optimality considerations of the firm, e.g. the firm could have made long term capital investments such as the installation of heavy machinery; alternatively, the assignment could be inherent to the product or service. The question why the firm follows a particular production plan, should not be pursued further, here. What is important, is the dominance of this production plan over incentive considerations; it is this dominance which allows to examine the design of incentives as depending on prescribed tasks.

The admittingly strong sequential assumption that the remuneration scheme is determined after posts are defined, assigns a direction to our interpretation of the relation between job characteristics and remuneration schemes; similar assumptions are explicitly and implicitly made by MacLeod and Parent (1998), Slade (1996), Dupuy and Lafranchi (1998) and Brown (1990). Without such an assumption, estimation results become mere indicators of correlation.

We suppose that tasks and combinations of tasks are linked to certain monitoring properties. As a consequence, performance is observable to both parties at some posts while only performance signals are available at others; 
in addition, the observability may be limited to firm and worker or include the public, so that the respective signals are verifiable at court.

Depending on the type and quality of information about the performance at the posts, the optimally choosen remuneration scheme will vary: if performance is not observable, performance signals have to be used; if performance or performance signals are not verifiable, self-enforcing agreements have to take the place of formal contracts (for an overview of self-enforcing agreements in labour relationships see Malcomson (1999)).

When performance signals are used their quality becomes an issue, where quality is typically associated with the variance and the bias of the signal. The variance unfolds its negative effect when the firm faces risk averse workers and has to trade off the advantage of performance related pay against a compensation for the risk forced on the workers. Despite this trade off, the information principle (Holmström (1979)) assures that no signal that bears information will be discarded. While a high variance does not lead to a suppression of signals, a large bias may have this consequence. The overwhelming negative effects of biased performance measures are manifested in many folkloristic examples (see e.g. Prendergast (1999)) and Holmström and Milgrom (1991) as well as Baker (1992) have proven that discarding biased signals may be optimal.

Typically, biased signals can be found when post descriptions are complex or when working at a post involves a multitude of tasks so that the objective of the firm cannot be completely covered by verifiable signals. Following the literature on costs of complex contracts (MacLeod 2000) and on multitasking (Baker 1992), we note:

Presumption 1 (complexity) When tasks at a post are complex, the incidence of contracts which formally link performance to remuneration (formal perfomance contracts) will be reduced.

Sometimes workers have to interact in a non-specifiable way in order to maximise the objective of the firm. Paying workers on individual achievements only, will induce them to neglect cooperation or coordination. This motivation to use team remuneration is theoretically explored by Drago and Turnbull (1988), Arya, Glover, and Hughes (1997), and Itoh (1991). This literature, leads us to the presumption:

Presumption 2 (cooperation) When interaction amongst workers is desired, team or group remuneration will be used more often, while the usage of individual remuneration will be reduced. 
If workers have to make decisions, individual performance remuneration may be problematic as the quality of decisions is difficult to assess. However, workers can be induced to internalise at least partially the consequences of their decision on firms objectives by linking their remuneration to firm performance measures.

Presumption 3 (responsability) If a posts requires decisions to be taken the incidence of remuneration based on firm performance will be larger.

The theoretical background of this presumption is the literature on investments (see e.g. Hart and Moore (1990)) where ownership induces an investor to incorperate consequences of the investment.

\section{The statistical model: three-variate probit}

In this section, we want to model statistically on which performance signals firms base their remuneration. The response variable $Y^{*}$ will reflect the performance signals which are used at the posts, while the explanatory variables $X$ will be task descriptors and post characteristics.

Assuming that signals are available on individual, team, and firm level, the firm has to choose between eight remuneration schemes. Formally, the remuneration scheme employed at post $j$ can be represented by a triple $\left(Y_{j i}^{*}, Y_{j t}^{*}, Y_{j f}^{*}\right)$ where the first entry $Y_{j i}^{*}$ indicates whether individual signals are used $\left(Y_{j i}^{*}=1\right)$ or not used $\left(Y_{j i}^{*}=0\right)$, the second entry $Y_{j t}^{*}$ indicates whether team signals are employed $\left(Y_{j t}^{*}=1\right)$ or not $\left(Y_{j t}^{*}=0\right)$, while the third dichotomous entry $Y_{j f}^{*}$ represents the choice with respect to firm signals (for an illustration see Table 1 while ignoring the depicted frequencies for the moment).

Suppose that the value of using a particular signal $k$ at post $j$ is perceived to be $Y_{j k}$ by the firm. Now, assume that the value of the signals as perceived by the firm depends on the task descriptors of this post $X_{j}$ in a linear way:

$$
\underbrace{\left(Y_{j i}, Y_{j t}, Y_{j f}\right)}_{Y_{j} .}=\underbrace{\left(X_{j i}\left|X_{j t}\right| X_{j f}\right)}_{X_{j} .} \underbrace{\left(\begin{array}{c}
\beta_{i} \\
\beta_{t} \\
\beta_{f}
\end{array}\right)}_{\beta}+\underbrace{\left(\epsilon_{j i}, \epsilon_{j t}, \epsilon_{j f}\right)}_{\epsilon_{j} .},
$$

where $X_{j} . \beta$ is the true value of using the signal and $\epsilon_{j}$ is an error vector which describes any uncertainty that the firm has about the value of the signals. 
This error vector should be multivariately normal distributed:

$$
\epsilon \sim \mathbb{N}\left(\left(\begin{array}{l}
0 \\
0 \\
0
\end{array}\right),\left(\begin{array}{ccc}
1 & \rho_{12} & \rho_{13} \\
\rho_{12} & 1 & \rho_{23} \\
\rho_{13} & \rho_{23} & 1
\end{array}\right)\right)
$$

where the variances are set to one for identification reasons. The firm will use a signal $k$ when its value exceeds a fixed value $y_{k}$, e.g. the costs of installing the new remuneration scheme. Hence, we get three equations for individual $(k=i)$, team $(k=t)$, and firm level $(k=f)$ of the following type:

$$
Y_{j k}^{*}=\left\{\begin{array}{l}
1 \text { for } Y_{j k} \leq \underline{y_{k}} \Leftrightarrow \epsilon_{j k} \leq-X_{j k} \beta_{k}, \\
0 \text { for } Y_{j k}>\underline{y_{k}} \Leftrightarrow \epsilon_{j k}>-X_{j k} \beta_{k},
\end{array}\right.
$$

and the decision of the firm is statistically described as a three-variate probit model.

Of course, there are alternative ways to model the relation between contracts based on individual, team, or firm level and task characteristics. In particular, one may think of the linear probability model and the multinomial logit model.

The linear probability model is known for its undesirable properties (see e.g. Davidson and MacKinnon (1993), p.512) and cannot be considered a serious alternative to the three-variate probit model. With respect to the multinomial model, we note that two of its assumptions are very unlikely to be fulfilled: (i) adding or surpressing team remuneration may very well alter the decision for or against firm remuneration and so the independence of irrelevant alternatives assumption would be violated and (ii) if the decision maker errs with respect to some intrinsic value of the remuneration on a particular level, say team remuneration, then the errors of the eight possible outcomes will be correlated and error terms are not independent.

\section{The ECMOSS data}

The data set which will be used for estimation stems from a survey called Enquête sur le Coût de la Main d'Oeuvre et la Structure des Salaires (ECMOSS) which was conducted in 1992 by the national statistical institute in France (INSEE). About ten thousand private establishments were randomly sampled and asked questions concerning labour costs; this explains the first part of the survey name: "Enquête sur le Coût de la Main d'Oeuvre" (survey 
on labour costs). Additionally, they were required to provide information on the salary structure and other characteristics for a subsample of their workers which is the reason for the second part of the survey name: "Enquête sur la Structure des Salaires". Moreover, questionnaires were sent to about 10,000 of the 150,000 subsampled workers.

As a result there is -in principle- information on about ca. 10,000 posts: data on payments, profession, and qualification provided by the establishment and descriptors for tasks supplied by the workers. To make the information from the two sources available at the same time the respective data sets are merged using official identifiers, date of birth, and gender. Since some of the observations cannot be uniquely matched, we are left with about 8,000 observations.

The data set includes information on payments made according to signals on individual, team and firm level. The observation of such payments is closely related to the usage of the respective signals in the incentive scheme. To get some idea on the relevance of the remuneration schemes, the frequencies of observed payments are presented in Table 1.

\begin{tabular}{rlrr}
\hline Coding & Observed payment conditioned on & Observations & Frequency \\
\hline 000 & no signals & 5259 & $65.4 \%$ \\
100 & only individual signals & 879 & $10.9 \%$ \\
010 & only team signals & 195 & $2.4 \%$ \\
001 & only firm signals & 1412 & $17.6 \%$ \\
110 & individual and team signals & 55 & $0.7 \%$ \\
101 & individual and firm signals & 140 & $1.8 \%$ \\
011 & team and firm signals & 78 & $1 \%$ \\
111 & individual, team and firm signals & 18 & $0.2 \%$ \\
\hline \multicolumn{4}{c}{ total } \\
\hline \multicolumn{3}{c}{ source: own calculations using ECMOss 1992 }
\end{tabular}

Table 1: Frequency of payments

Coding refers to the coding of signal usage for the statistical model as introduced in section 3.

\section{Testable implications}

This section will describe the data in more detail and explain whether and how it can be employed to check the three presumptions formulated in sec- 
tion 2. First, the variables and problems of measuring remuneration are discussed. Then, the variables describing posts are dealt with.

The data set contains no explicit information on the signal usage at the different aggregation levels but only the size of individual, team, and firm performance payments. Even when no payment is observed for a particular signal, this does not mean that the signal is not included in the remuneration scheme. If the remuneration function specifies that payments should only occur, when the performance of a worker exceeds a certain threshold, then it is very well possible, that the lack of performance led to the fact that no payment was observed, while the payment principally relies on that signal.

To circumvent this problem one can put structural assumptions on the distributions of the performance shock. However, this exercise would only be useful if all contracts were threshold contracts. For other types of contracts, such as linear contracts, the correction has to be different. As we have no means to distinguish between the different contract types from the data, we cannot pursue this avenue.

Alternatively, one could correct for the misclassification by extending the approach of Hausman, Abrevaya, and Scott-Morton (1998) to multivariate response-variables. The limitation of this approach is the required independence of the misclassification from post characteristics which is very likely to be violated. ${ }^{1}$

Hence, we will use observed performance payment as an indicator for a perfomance pay contract based on the respective signal, hoping that the former proxies the latter sufficiently well and being aware that we most likely observe too few performance pay contracts and that estimation results may be downwardly biased.

There is a second aspect concerning the characterisation of the remuneration scheme: it is not possible to identify from the data whether a bonus resulted from an explicit contract or from an informal agreement. As the first presumption deals with the formal use of signals, one has to be very careful when trying to evaluate this presumption using the ECMOSS data.

\footnotetext{
${ }^{1}$ As Jospeh Lafranchi pointed out correctly, the usage of signals is more likely to be observed if the respective payment is large. Hence, if size of payment is related to post characteristics, a modification of Hausman, Abrevaya, and Scott-Morton (1998) cannot be used. Future research of the author will try to address both: the misclassification and the selectivity issue.
} 
To describe the tasks at the post, we consider variables which indicate whether

- administrative tasks are required at the post (MANAGE),

- evaluation of other workers has to be carried out without effect on their salary (EVALUATE) and with effect on their salary (JUDGE),

- the work is defined by a precise description of tasks (EXECUTE),

- non-hierarchical professional contacts are required (COOPERATE),

- minor problems are solved without referring to the hierarchy (RESPONS).

The exact definition of these variables can be found in the appendix (see Table 4.

MANAGE, EVALUATE, and JUDGE indicate complex multitask activities and by the complexity presumption, they should reduce the incidence of formal signal usage. On the other hand, MANAGE implies that decisions have to be taken, so that the responsibility presumption suggests an increased employment of firm signals. The variable JUDGE is problematic, since it might not only be linked to multitasking but could be directly related to the remuneration scheme; i.e. someone who "judges" might be likely to be "judged" due to characteristics of the working environment which are not reflected by other observed variables. This environmental effect will only prevail on the individual level as such an effect on the team or firm level would imply that the worker has to judge himself.

The variable EXECUTE should have a negative effect on signal usage according to the complexity presumption: if very precise objectives can be given, this indicates a simple situation in which we expect more formal performance signal usage. From the cooperation presumption, COOPERATE will have a positive effect on more aggregated signals while it reduces the importance of individual signals. If minor problems are solved without referring to the hierarchy, the worker needs sufficient incentives to solve these problems in the interest of the firm; according to the responsibility presumption, RESPONS should therefore increase the usage of firm signals.

To describe the time aspect of the firm-worker relationship, the following three variables are analysed: FSENIOR gives the length of employment at 
the firm, PSENIOR is the time spent at the present post, and TEMPORARY indicates whether the worker was employed the full survey year. These timing variables influence whether relational contracts can be enforced. Being at the firm for a long time (FSENIOR) enables the firm to use promotion as an individual remuneration device, so that individual bonus payments are not necessary. Firm and team bonuses may lead the workers to identify with the work environment, so that workers are less likely to quit. A long time spent at the present post (PSENIOR) hints to the fact that promotion is not or cannot be used as a remuneration device; hence, we would expect more individual bonus payments. At the same time, it can also indicate that individual signals are sufficient as incentives so that team and firm signals are not required. If the relationship between worker and firm is not well established (TEMPORARY), promotion and other relation related remuneration methods are precluded and individual performance pay has to be employed. On the other hand, not getting firm or team remuneration reduces identification with the employer and may induce the worker to quit more easily.

The expected effects are summarised in Table 2. Once again, it should be

Table 2: Expected effects

\begin{tabular}{rllll}
\hline \hline Variable & presumption & I & T & F \\
\hline MANAGE & complexity & - & - & - \\
& responsability & & & + \\
JUDGE & complexity & - & - & - \\
& see text & + & & \\
EVALUATE & complexity & - & - & - \\
EXECUTE & complexity & + & + & + \\
RESPONS & responsability & & & + \\
COOPERATE & cooperation & - & + & + \\
\hline FSENIOR & see text & - & + & + \\
PSENIOR & see text & + & - & - \\
TEMPORARY & see text & + & - & - \\
\hline
\end{tabular}

The column headings I, T, and F refer to the incidence of using individual, team, and firm signals.

pointed out that the effects stemming from the complexity presumption concern the incidence of formal signal usage. Only if this formal signal usage is positively related to the respective usage of performance remuneration, the effects will be present. 


\section{Results}

After the deletion of observations for which variables had missing values, about 7,200 observations are left to estimate model (3).

Additionally, to the variables of interest specified in the previous section, we used the following control variables: profession on a 2-digit level (finer levels are available but do not yield sufficiently many observations), five categories describing the post in the establishment, the number of remunerated hours, six educational dummies, nine age dummies, the gender of the worker, and family status.

The estimations were carried out using maximum likelihood techniques and the Newton-Raphson method. To estimate correlations between the error terms three bi-variate probit models are estimated; convergence is achieved. The Wald $-\chi^{2}$ test for model identification strongly rejects any model which does not depend on the explanatory variables in all three estimations.

Table 3 presents the results of the estimations in terms of a change of the probability when the respective explanatory variable is altered and all other variables are evaluated for an average post. Looking at the results, we conclude: if it is necessary to judge others (JUDGE), this increases the incidence of individual performance remuneration and has no effect on aggregated signals. This finding can be explained by the environmental effect. The reduction of signals which we expect from the complexity presumption cannot be observed. Likewise, doing administrative tasks (MANAGE), evaluating other workers (EVALUATE) and having a precise task description (EXECUTE) do not show the effects predicted by the complexity presumption.

In full accordance with the responsibility presumption, the incidence of firm signals is strongly increased when it is necessary that minor problems have to be solved by the occupant of the post without referring to the hierarchy: the probability of being remunerated on firm signals increases about $4 \%$ for an otherwise ordinary post. Slightly disturbing might be the negative sign with respect to team signals which has a P-value of about $7 \%$.

The cooperation presumption is also fully supported by the data. If nonhierarchical contacts are required at a specific post, this decreases individual performance pay about $1.5 \%$, and increases the incidence of team performance pay by $1 \%$ and that of firm performance pay by $3 \%$, where all changes are highly significant. 
Table 3: Estimated change in marginal effects

\begin{tabular}{|c|c|c|c|c|c|c|}
\hline \multirow[b]{2}{*}{ Variable } & \multicolumn{2}{|c|}{ Individual } & \multicolumn{2}{|c|}{ Team } & \multicolumn{2}{|c|}{ Firm } \\
\hline & $\frac{\Delta P}{\Delta X}$ & P-value & $\frac{\Delta P}{\Delta X}$ & P-value & $\frac{\Delta P}{\Delta X}$ & P-value \\
\hline MANAGE & -.016 & 0.191 & $\begin{array}{l}\Delta \lambda \\
-.001\end{array}$ & 0.896 & -.003 & 0.846 \\
\hline JUDGE & .068 & $0.001^{* * *}$ & .009 & 0.410 & -.013 & 0.505 \\
\hline EVALUATE & -.012 & 0.529 & .006 & 0.581 & -.025 & 0.229 \\
\hline EXECUTE & -.002 & 0.821 & -.007 & 0.177 & .004 & 0.671 \\
\hline RESPONS & -.005 & 0.564 & -.010 & $0.071^{*}$ & .039 & $0.000 * * *$ \\
\hline COOPERATE & -.014 & $0.100^{*}$ & .010 & $0.034^{* *}$ & .027 & $0.008^{* * *}$ \\
\hline FSENIOR & -.012 & $0.028^{* *}$ & .005 & $0.077^{*}$ & .044 & $0.000 * * *$ \\
\hline PSENIOR & .009 & $0.039 * *$ & -.005 & $0.055^{*}$ & -.033 & $0.000 * * *$ \\
\hline TEMPORARY & -.024 & 0.186 & .004 & 0.726 & -.124 & $0.000 * * *$ \\
\hline BLUE COLLAR & .026 & 0.227 & -.013 & 0.194 & -.037 & 0.118 \\
\hline WHITE COLLAR & & refe & ence gr & up & & \\
\hline TECHNICIAN & .045 & $0.044^{* *}$ & .024 & $0.098^{*}$ & .005 & 0.839 \\
\hline MASTER & .007 & 0.733 & -.016 & 0.159 & .034 & 0.174 \\
\hline MANAGER & .051 & $0.079^{*}$ & .001 & 0.968 & .022 & 0.497 \\
\hline FEMALE & -.035 & $0.000 * * *$ & -.005 & 0.323 & -.028 & $0.013^{* *}$ \\
\hline & $\begin{array}{r}\text { age } \\
\text { educati } \\
\text { professi } \\
\text { fa } \\
\text { ho }\end{array}$ & $\begin{array}{l}\text { lummies } \\
\text { n dummi } \\
\text { n dummi } \\
\text { iily status } \\
\text { irs worked }\end{array}$ & $\begin{array}{l}\text { (5) } \\
(21)\end{array}$ & & & \\
\hline
\end{tabular}

*** significant on $1 \%$ level, ** significant on $5 \%$ level, * significant on $10 \%$ level The given P-values are from a WALD test on the coefficients determining the change in the probability 
For the period of time spent at the firm (FSENIOR) the hypothesised effects seem to be present: for long periods significantly higher incidences of team and firm performance pay can be observed. With respect to individual signals, the expected reduction takes place.

The results for the time length since the last promotion (PSENIOR), indicates that individual performance pay and performance pay on aggregated signals together with implicit contracts are two alternative remuneration packages which are used as substitutes. The choice between those substitutes could be explained by the cooperation or responsibility hypothesis. Nevertheless, it would be interesting to explore this bundle characteristic further.

Having not worked permanently at the firm in the surveyed year (TEMPORARY), has a highly significant effect on reducing the incidence of firm performance pay. However, no increase in individual performance remuneration can be observed.

The three-variate probit also allows us to estimate the correlation between the error terms. From these correlations, it can be concluded that beyond the influence of the explanatory variables, individual and firm signal remuneration schemes are rather substitutes; the respective correlation is -.2 and highly significant. Not surprisingly remunerations based on signals of neighbouring aggregation levels are positively correlated: in both cases the correlation is around .09.

To check for robustness of our results, we also estimate the linear probability model and the multinomial model using ordinary least squares and maximum likelihood. The estimates from the linear probability model are surprisingly close; often they conincide up to the third decimal place (see Table 5 in the appendix). Less strinkingly, estimation of the multinomial logit supports the major findings from the three-variate probit model concerning signs and significance in accordance with the responsability and the cooperation presumption and evidence about the complexity presumption remains mixed.

Another objection one might raise against the three-variate probit model is the following: maybe, the general decision whether to use performance pay is intrinsically different from the decision to use a particular type of performance pay. One could imagine that the decision to remunerate workers based on some performance measure is made before the firm decides on the measure. To check whether this influences our results, we re-estimate the 
probit model using only observations where at least one form of performance remuneration was given. While the actual estimates differ, signs and significance levels remain unchanged.

Overall, we conclude from the three alternative specifications that the support of the data for the responsability and the cooperation presumption is fairly robust.

Slade (1996) finds more convincing evidence in favour of multitask effects. Differing from our analysis she has very precise measures concerning the number and type of tasks for otherwise rather homogenous posts at gas stations in Vancouver. Hence, the bad standing of the complexity presumption in our case can probably be traced back to our imprecise measure of multitasking. Recall also, that the complexity presumption makes a statement about formal performance contracts while we observe formal and informal remunerations pooled. So it might very well be, that the reduction of formal performance pay in multitask settings is present in the data but cannot be observed since it is compensated by an increase of informal bonuses and not by a decrease in bonus payments.

Using firm level data, Goldin (1986) observed that firms with a large proportion of women use piece rates significantly more often while we find that being a woman reduces the incident of signal based remuneration significantly on individual and on the firm level. On first sight, our findings stands in contrast to the argument put forward by Goldin, that women should more often get performance pay than men as unemployment spells due to child rearing reduce the scope for implicit or relational contracts. This argument hinges on the time-wise different employer-employee relationship which is in our analysis controlled for by FSENIOR, PSENIOR, and TEMPORARY. Since Goldin worked on the aggregate level, similar information was not at her disposal. Using this information, we find support for her argument. Nevertheless, a non-negligible difference between men and women pertains after controlling for the differences in employment time. This difference cannot be explained by the above reasoning.

Performance pay in form of piece rates is theoretically predicted and usually found to be positively correlated with higher compensation (see Seiler (1984), Brown (1992) or Pelé (1997)). As our data suggest that women receive performance pay less often, it would be interesting to know how much of the wage gap between men and women can be attributed to this difference of receiving performance payments. 


\section{Conclusion}

It was the goal of our analysis to shed some light on firm's choice of remuneration schemes, i.e. we attempted to explain how firms alleviate the hidden action problem which prevails in many employer-employee relationships. We focused on the level at which worker's performance is evaluated.

Drawing from the large theoretical literature on incentives, three presumptions were formulated which link task characteristics to the choice of the firm whether or not to remunerate based on individual, team, and firm performance. The choice of firms amongst these alternatives were modeled statistically by a three-variate probit model. Matching data on post characteristics and remuneration methods stemming from a survey on private French establishments rendered the estimation of the statistical model feasible.

Controlling for profession, demographic information, and hierarchical position, we find support for two of the presumptions: jobs which require decision making are likely to be coupled with firm performance pay (responsability presumption) and jobs which necessitate coordination and cooperation come along with less usage of individual and more usage of aggregated performance measures (cooperation presumption). Evidence for a reduced employment of formal performance measures in complex situations (complexity presumption) is mixed. Here, results are hampered by the fact that the information whether signals are used formally is not explicit in the data.

\section{References}

Arya, A., J. Glover, and J. S. Hughes (1997): "Implementing Coordinated Team Play," Journal of Economic Theory, 74(1), 218-232.

BAKer, G. (1992): "Incentive Contracts and Performance Measurement," Journal of Political Economy, 100(3), 598-614.

Baker, G., R. Gibbons, and K. J. Murphy (1999): "Relational Contracts and the Theory of the Firm," Discussion paper, NBER Working Paper.

Brown, C. (1990): "Firm's Choice of Method of Pay," Industrial and Labor Relations Review, 43(3), 165S-183S, Special Issue.

(1992): "Wage Levels and the Method of Pay," Rand Journal of Economics, 23(3), 366-375. 
Bull, C. (1987): "The Existence of Self-Enforcing Implicit Contracts," The Quaterly Journal of Economics, 102, 147-159.

Davidson, R., And J. G. MacKinnon (1993): Estimation and Inference in Econometrics. Oxford University Press, Oxford.

Drago, R., And G. Turnbull (1988): "Individual versus Group Piece Rates under Team Technologies," Japanese and International Economies, $2,1-10$.

Dupuy, K., AND J. LAfranchi (1998): "Performance absolue ou relative? Comment les etablissement francais choisisent-ils leurs primes salariales?," Discussion paper, Document de Travail ERMES 98.06.

Dye, R. (1986): "Optimal monitoring policies in agencies," Rand Journal of Economics, 17(3), 339-350.

Gibbons, R. (1996): Advances in Economics and Econometrics: Theory and Applicationschap. Incentive and Careers in Organisations, pp. 1-37. Cambridge University Press, Cambridge.

Goldin, C. (1986): "Monitoring Costs and Occupational Segregation by Sex," Journal of Labor Economics, 4(1), 1-27.

Green, J. R., and N. L. Stockey (1983): "A Comparison of Tournaments and Contracts," Journal of Political Economy, 91(3), 349-364.

Hart, O., And J. Moore (1990): "Property Rights and the Nature of the Firm," Journal of Political Economy, 98, 1119-1158.

Hausman, J., J. Abrevaya, And F. Scott-Morton (1998): "Missclassification of the Dependent Variable in a Discrete-Response setting," Journal of Econometrics, 87, 239-269.

Holmström, B. (1979): "Moral Hazard and Observability," Bell Journal of Economics, 10(1). $324-340$.

Holmström, B., And P. Milgrom (1991): "Multitask Principal-AgentAnalysis: Incentive Contracts, Asset Ownership, and Job Design," Journal of Law, Economics, and Organization, 7, 24-52. 
Iтон, H. (1991): "Incentives to Help in Multi-Agent Situations," Econometrica, 59(3), 611-636.

LazeAr, E. (1995): Personnel Economics. MIT Press, Cambridge, Massachusetts.

LAzEAR, E., AND S. Rosen (1981): "Rank Order Tournaments as Optimal Labor Contracts," Journal of Political Economy, 89(5), 841-864.

MacLeod, W. B. (2000): "Complexity and Contract," Revue d'Economie Industrielle.

Macleod, W. B., and D. Parent (1998): "Job Characteristics and the Form of Compensation," Discussion paper, CIRANO Document de travail.

Malcomson, J. M. (1999): "New Developments in the Study of Contracts on Labor Markets," in Handbook of Labor Economics, ed. by O. Ashenfelter, and D. Card, vol. 3B. Elsevier, Amsterdam, 5 edn.

PelÉ, L.-P. (1997): "Methods of Pay, Worker Selection, and Minimum Wage," Discussion paper, Document de Travail CREST (9721).

Prendergast, C. (1999): "The Provision of Incentives in Firms," Journal of Economic Literature, XXXII, 7-63.

Rosen, S. (1985): "Implicit contracts: a survey," Journal of Economic Literature, XXXIII(3), 1144-1175.

SAlaniÉ, B. (1998): Economics of contracts. MIT Press.

SeIler, E. (1984): "Piece Rate vs. Time Rate: The Effect of Incentives on Earnings," The Review of Economics and Statistics, LXVI(3), 363-376.

Shapiro, C., And J. Stiglitz (1984): "Equilibrium Unemployment as a Worker Discipline Device," American Economic Review, 74, 433-444.

Slade, M. E. (1996): "Multitask Agency and Contract Choice: An Empirical Exploration," International Economic Review, 37(2), 465-486. 


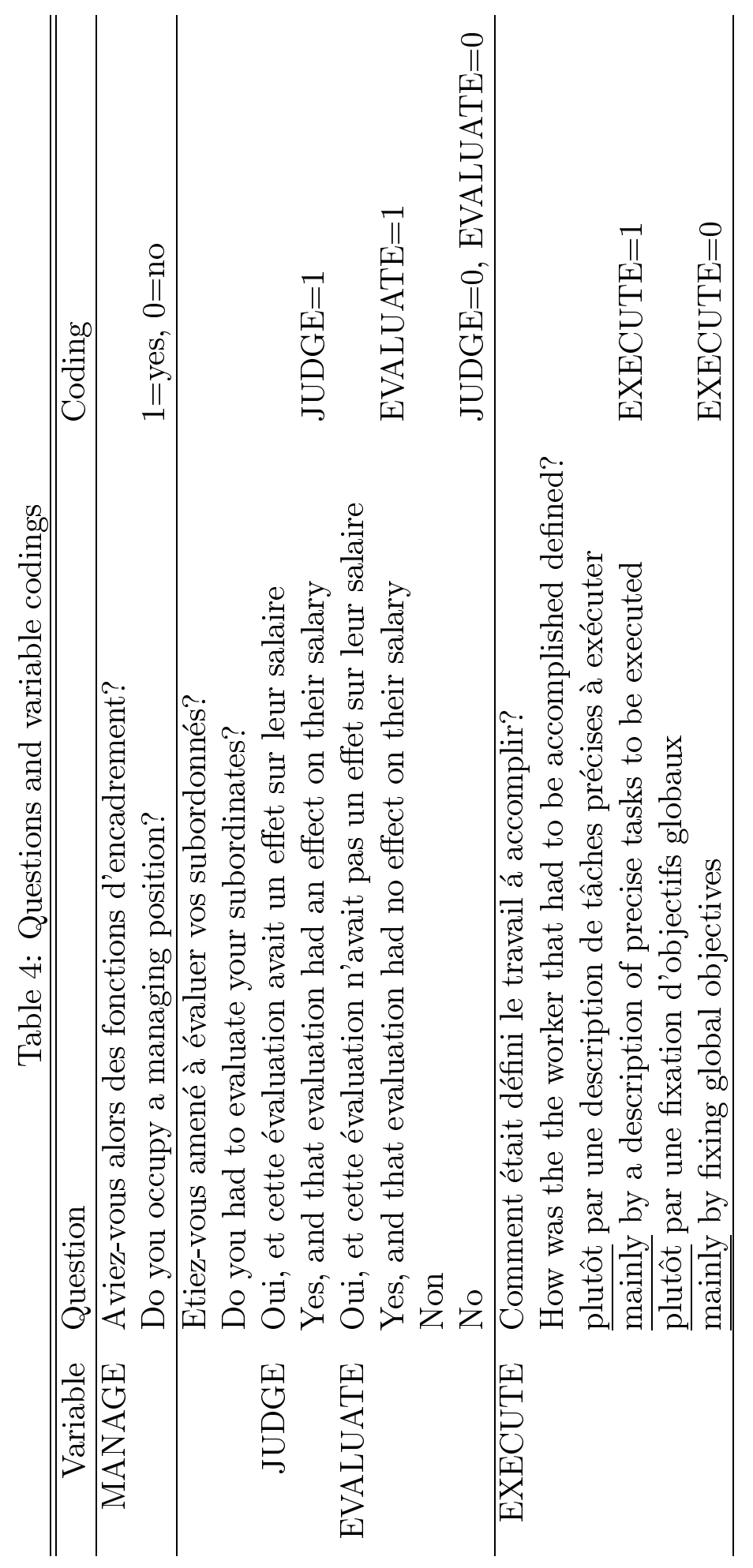




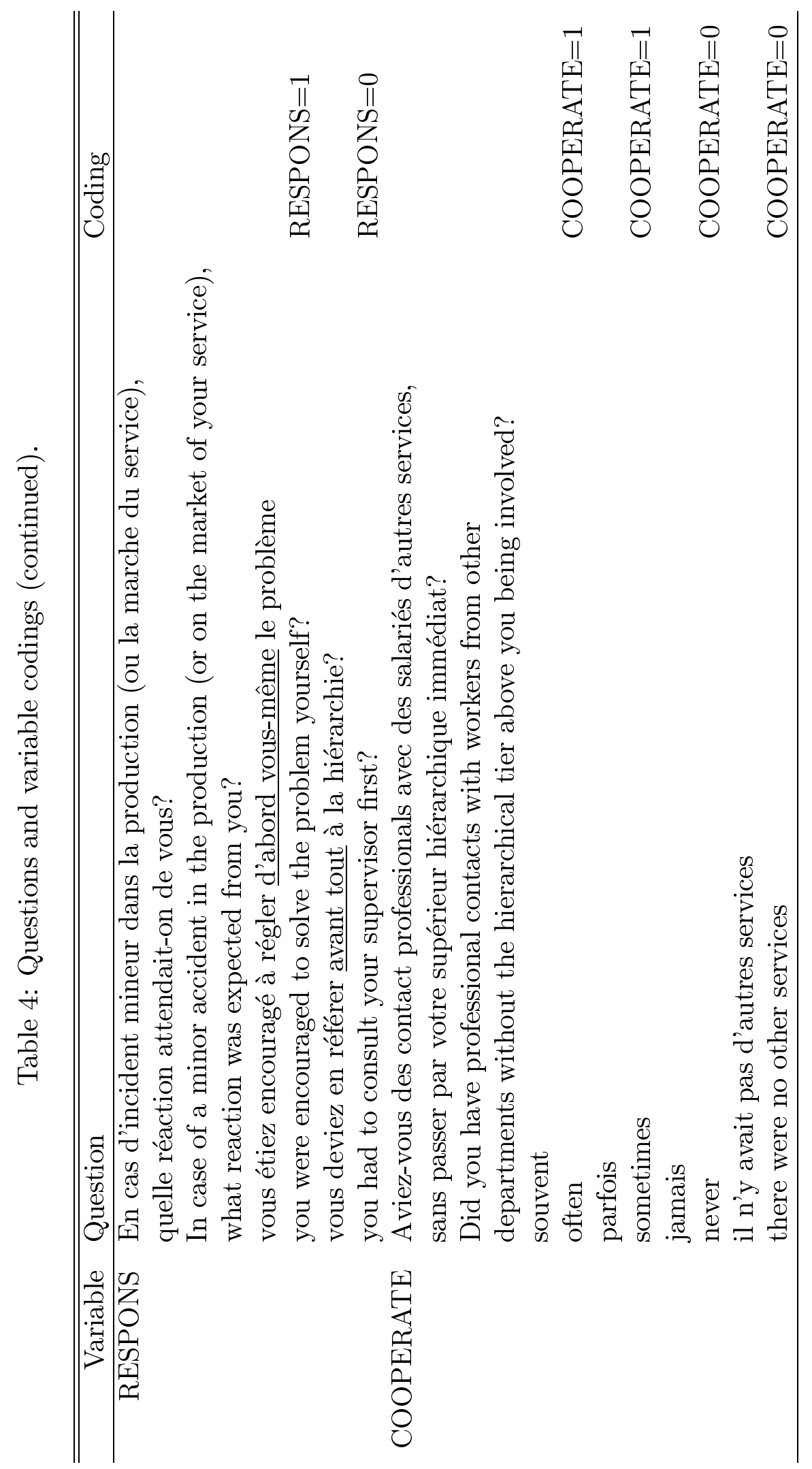


Table 5: Alternative model specifications

\begin{tabular}{|c|c|c|c|c|c|c|c|c|}
\hline & \multicolumn{2}{|c|}{ Linear probability } & \multicolumn{2}{|c|}{ Multinomial logit } & \multicolumn{2}{|c|}{ Probit (without 000) } & \multicolumn{2}{|c|}{ Probit } \\
\hline Individual & $\Delta \mathrm{P} / \Delta \mathrm{X}$ & p-Value & $\Delta \mathrm{P} / \Delta \mathrm{X}$ & p-Value & $\Delta \mathrm{P} / \Delta \mathrm{X}$ & p-Value & $\Delta \mathrm{P} / \Delta \mathrm{X}$ & p-Value \\
\hline MANAGE & -0.016 & 0.213 & -0.026 & 0.212 & -0.040 & 0.221 & -0.016 & 0.191 \\
\hline JUDGE & 0.066 & $0.001 * * *$ & 0.169 & $0.007 * * *$ & 0.169 & $0.000 * * *$ & 0.068 & $0.001 * * *$ \\
\hline EVALUATE & -0.008 & 0.664 & -0.021 & 0.532 & 0.015 & 0.750 & -0.012 & 0.529 \\
\hline EXECUTE & -0.002 & 0.775 & 0.007 & 0.699 & -0.004 & 0.844 & -0.002 & 0.821 \\
\hline RESPONS & -0.005 & 0.603 & -0.014 & 0.424 & -0.358 & 0.145 & -0.005 & 0.564 \\
\hline COOPERATE & -0.014 & 0.106 & -0.020 & 0.185 & -0.048 & $0.032 * *$ & -0.014 & $0.100 *$ \\
\hline R2 / pseudo R2 & 0.038 & & see & & 0.098 & & 0.053 & \\
\hline Log likelihood & & & below & & -1554 & & -2749 & \\
\hline $\begin{array}{l}\text { Observations } \\
\text { Team }\end{array}$ & 7281 & & & & 2586 & & 7283 & \\
\hline MANAGE & 0.000 & 0.965 & 0.029 & $0.065^{*}$ & -0.012 & 0.574 & -0.001 & 0.896 \\
\hline JUDGE & 0.009 & 0.381 & -0.011 & 0.335 & 0.038 & 0.245 & 0.009 & 0.410 \\
\hline EVALUATE & 0.006 & 0.602 & -0.020 & $0.007 * * *$ & 0.054 & 0.137 & 0.006 & 0.581 \\
\hline EXECUTE & -0.005 & 0.163 & -0.003 & 0.689 & -0.018 & 0.205 & -0.007 & 0.177 \\
\hline RESPONS & -0.011 & $0.051 *$ & -0.012 & $0.024 * *$ & -0.386 & $0.016 * *$ & -0.010 & $0.071 *$ \\
\hline COOPERATE & 0.012 & $0.026 * *$ & 0.010 & 0.201 & 0.025 & $0.075 *$ & 0.010 & $0.034 * *$ \\
\hline R2 / pseudo R2 & 0.024 & & see & & 0.06 & & 0.062 & \\
\hline Log likelihood & & & below & & -888 & & -1198 & \\
\hline $\begin{array}{l}\text { Observations } \\
\text { Firm }\end{array}$ & 7281 & & & & 2497 & & 6917 & \\
\hline MANAGE & -0.002 & 0.86 & 0.047 & 0.161 & 0.026 & 0.441 & -0.003 & 0.846 \\
\hline JUDGE & -0.01 & 0.651 & -0.052 & 0.127 & -0.132 & $0.005 * * *$ & -0.013 & 0.505 \\
\hline EVALUATE & -0.027 & 0.211 & -0.023 & 0.563 & -0.058 & 0.253 & -0.025 & 0.229 \\
\hline EXECUTE & 0.005 & 0.638 & -0.025 & 0.218 & 0.012 & 0.579 & 0.004 & 0.671 \\
\hline RESPONS & 0.038 & $0.000 * * *$ & 0.055 & $0.044 * *$ & 0.077 & $0.002 * * *$ & 0.039 & $0.000 * * *$ \\
\hline COOPERATE & 0.029 & $0.004 * * *$ & 0.040 & $0.089 *$ & 0.064 & $0.005 * * *$ & 0.027 & $0.008 * * *$ \\
\hline R2 / pseudo R2 & 0.127 & & 0.210 & & 0.113 & & 0.136 & \\
\hline Log likelihood & & & -6796 & & -1538 & & -3268 & \\
\hline Observations & 7281 & & 7283 & & 2586 & & 7278 & \\
\hline
\end{tabular}

*** significant on $1 \%$ level, ** significant on $5 \%$ level, * significant on $10 \%$ level. The given P-values are from a WALD test on the coefficients determining the change in the probability. 


\section{IZA Discussion Papers}

No Author(s)

141 R. Hujer M. Wellner

142 J. J. Dolado

F. Felgueroso

J. F. Jimeno

143 P. J. Luke

M. E. Schaffer

144 G. Saint-Paul

145 M.-S. Yun

146 T. K. Bauer

J. P. Haisken-DeNew

147 M. Belot

J. C. van Ours

148 L. Goerke

149 R. Lalive

J. C. van Ours

J. Zweimüller

150 J. DiNardo

K. F. Hallock

J.-St. Pischke

151 M. Ward

152 J. J. Dolado

F. Felgueroso

J. F. Jimeno

153 A. S. Kalwij

M. Gregory

154 M. Gerfin

M. Lechner

155 J. Hansen
Titel

Area

Date

The Effects of Public Sector Sponsored Training on Individual Employment Performance in East Germany

Explaining Youth Labor Market Problems in Spain: 3 Crowding-Out, Institutions, or Technology Shifts?

Wage Determination in Russia: An Econometric 4 Investigation

$4 / 00$

Flexibility vs. Rigidity: Does Spain have the worst of 1 both Worlds?

Decomposition Analysis for a Binary Choice Model 7

$4 / 00$

Employer Learning and the Returns to Schooling 5

$4 / 00$

$4 / 00$

Does the Recent Success of Some OECD 3

3

Countries in Lowering their Unemployment Rates

Lie in the Clever Design of their Labour Market

Reforms?

Employment Effects of Labour Taxation in an Efficiency Wage Model with Alternative Budget Constraints and Time Horizons

The Impact of Active Labor Market Programs and Benefit Entitlement Rules on the Duration of Unemployment

Unions and the Labor Market for Managers

Gender, Salary and Promotion in the Academic 5 Profession

$5 / 00$

The Role of the Minimum Wage in the Welfare 3 State: An Appraisal

$5 / 00$

Overtime Hours in Great Britain over the Period 3 1975-1999: A Panel Data Analysis

Microeconometric Evaluation of the Active Labour 6 Market Policy in Switzerland

$5 / 00$

$5 / 00$

The Duration of Immigrants' Unemployment Spells: $\quad 1 / 3$ Evidence from Sweden 


\begin{tabular}{|c|c|c|c|c|}
\hline 156 & $\begin{array}{l}\text { C. Dustmann } \\
\text { F. Fabbri }\end{array}$ & $\begin{array}{l}\text { Language Proficiency and Labour Market Per- } \\
\text { formance of Immigrants in the UK }\end{array}$ & 1 & $5 / 00$ \\
\hline 157 & $\begin{array}{l}\text { P. Apps } \\
\text { R. Rees }\end{array}$ & $\begin{array}{l}\text { Household Production, Full Consumption and } \\
\text { the Costs of Children }\end{array}$ & 7 & $5 / 00$ \\
\hline 158 & $\begin{array}{l}\text { A. Björklund } \\
\text { T. Eriksson } \\
\text { M. Jäntti } \\
\text { O. Raaum } \\
\text { E. Österbacka }\end{array}$ & $\begin{array}{l}\text { Brother Correlations in Earnings in Denmark, } \\
\text { Finland, Norway and Sweden Compared to the } \\
\text { United States }\end{array}$ & 5 & $5 / 00$ \\
\hline 159 & $\begin{array}{l}\text { P.- J. Jost } \\
\text { M. Kräkel }\end{array}$ & Preemptive Behavior in Sequential Tournaments & 5 & $5 / 00$ \\
\hline 160 & M. Lofstrom & $\begin{array}{l}\text { A Comparison of the Human Capital and Signaling } \\
\text { Models: The Case of the Self-Employed and the } \\
\text { Increase in the Schooling Premium in the 1980's }\end{array}$ & 5 & $6 / 00$ \\
\hline 161 & $\begin{array}{l}\text { V. Gimpelson } \\
\text { D. Treisman } \\
\text { G. Monusova }\end{array}$ & $\begin{array}{l}\text { Public Employment and Redistributive Politics: } \\
\text { Evidence from Russia's Regions }\end{array}$ & 4 & $6 / 00$ \\
\hline 162 & $\begin{array}{l}\text { C. Dustmann } \\
\text { M. E. Rochina- } \\
\text { Barrachina }\end{array}$ & $\begin{array}{l}\text { Selection Correction in Panel Data Models: An } \\
\text { Application to Labour Supply and Wages }\end{array}$ & 6 & $6 / 00$ \\
\hline 163 & $\begin{array}{l}\text { R. A. Hart } \\
\text { Y. Ma }\end{array}$ & Why do Firms Pay an Overtime Premium? & 5 & $6 / 00$ \\
\hline 164 & $\begin{array}{l}\text { M. A. Shields } \\
\text { S. Wheatley Price }\end{array}$ & $\begin{array}{l}\text { Racial Harassment, Job Satisfaction and Intentions } \\
\text { to Quit: Evidence from the British Nursing } \\
\text { Profession }\end{array}$ & 5 & $6 / 00$ \\
\hline 165 & P. J. Pedersen & $\begin{array}{l}\text { Immigration in a High Unemployment Economy: } \\
\text { The Recent Danish Experience }\end{array}$ & 1 & $6 / 00$ \\
\hline 166 & $\begin{array}{l}\text { Z. MacDonald } \\
\text { M. A. Shields }\end{array}$ & $\begin{array}{l}\text { The Impact of Alcohol Consumption on Occupa- } \\
\text { tional Attainment in England }\end{array}$ & 5 & $6 / 00$ \\
\hline 167 & $\begin{array}{l}\text { A. Barrett } \\
\text { J. FitzGerald } \\
\text { B. Nolan }\end{array}$ & $\begin{array}{l}\text { Earnings Inequality, Returns to Education and } \\
\text { Immigration into Ireland }\end{array}$ & 5 & $6 / 00$ \\
\hline 168 & $\begin{array}{l}\text { G. S. Epstein } \\
\text { A. L. Hillman }\end{array}$ & $\begin{array}{l}\text { Social Harmony at the Boundaries of the Welfare } \\
\text { State: Immigrants and Social Transfers }\end{array}$ & 3 & $6 / 00$ \\
\hline 169 & R. Winkelmann & $\begin{array}{l}\text { Immigration Policies and their Impact: The Case of } \\
\text { New Zealand and Australia }\end{array}$ & 1 & $7 / 00$ \\
\hline 170 & $\begin{array}{l}\text { T. K. Bauer } \\
\text { K. F. Zimmermann }\end{array}$ & $\begin{array}{l}\text { Immigration Policy in Integrated National } \\
\text { Economies }\end{array}$ & 1 & $7 / 00$ \\
\hline 171 & $\begin{array}{l}\text { C. Dustmann } \\
\text { F. Windmeijer }\end{array}$ & $\begin{array}{l}\text { Wages and the Demand for Health - A Life Cycle } \\
\text { Analysis }\end{array}$ & 5 & $7 / 00$ \\
\hline 172 & D. Card & $\begin{array}{l}\text { Reforming the Financial Incentives of the Welfare } \\
\text { System }\end{array}$ & 3 & $7 / 00$ \\
\hline 173 & D. S. Hamermesh & Timing, Togetherness and Time Windfalls & 5 & $7 / 00$ \\
\hline
\end{tabular}



M. Ward

180 T. K. Bauer I. N. Gang

E. Wasmer

Y. Zenou

184 M. Corak

B. Gustafsson

T. Österberg

185 H. Bonin

K. F. Zimmermann

A. S. Kalwij

A. Zaidi 
223 M. Rosholm former Soviet Union to Israel: Who is coming when?

228 G. Brunello

S. Comi

C. Lucifora

229 R. Coimbra

T. Lloyd-Braga

L. Modesto

230 L. Modesto

C. Dustmann

C. M. Schmidt

234 R. Rotte M. Steininger
The College Wage Gap in 10 European

Countries: Evidence from Two Cohorts

Unions, Increasing Returns and Endogenous

Fluctuations

Should I Stay or Should I Go? Educational Choices

5 and Earnings: An Empirical Study for Portugal

The Economics of Human Cloning

5

$12 / 00$

The Effect of Non-Standard Employment on

5

$12 / 00$ Mental Health in Britain

The Wage Performance of Immigrant Women:

Full-Time Jobs, Part-Time Jobs, and the Role of

\section{Selection}

Sozioökonomische Determinanten extremistischer 3 Wahlerfolge in Deutschland: Das Beispiel der Europawahlen 1994 und 1999

Who gets the Reward? An Empirical Exploration 5 $12 / 00$ 